\title{
$\begin{array}{lllllll}P & \boldsymbol{r} & \boldsymbol{i} & \boldsymbol{n} & \boldsymbol{O} & \mathrm{s} & \boldsymbol{i}\end{array}$
}

\section{NEKI ELEMENTI MEĐURELIGIJSKE KOMPETENCIJE IZ PERSPEKTIVE VJERONAUČNE DIDAKTIKE}

\author{
Jadranka Garmaz - Hans Mendl
}

Sveučilište u Splitu

UDK: 37.02:2]:27-752

Katolički bogoslovni fakultet

27-67:27-727

jadrankagarmaz@gmail.com

$24-673.5$

Universität Passau

mendl@uni-passau.de

https://doi.org/10.34075/cs.56.2.5

Pregledni znanstveni rad

Rad zaprimljen 12/2020.

\section{Sažetak}

Kontekst religijskog obrazovanja u Europi obilježen je kulturnim, religioznim i sujetonazorskim pluralizmom. Stoga članak iz religijsko didaktičke perspektive obrađuje kriterije i elemente koji pripadaju međureligijskoj kompetenciji u katoličkom vjeronauku.

U prvom se poglavlju analiziraju temeljni pojmovi koji se odnose na učenje o religiji, $s$ posebnim naglaskom na razlikovanje pojmova međureligijska, višereligijska, transreligijska i transverzalna kompetencija. U drugom se poglavlju sažeto prikazuju neki religijsko didaktički kriteriji, elementi $i$ načela međureligijske kompetencije $u$ konfesionalnom katoličkom vjeronauku. U trećem poglavlju otvaraju se nove istraživačke perspektive unutar područja komparativne religijske pedagogije. Pretpostavljajući stavove uvažavanja, spremnosti na promjenu i uspostavljanje prijateljstava, međureligijska se kompetencija dokazuje kao neizostavna upravo u odgoju za suživot u pluralnom društvu. U religijskom obrazovanju ona ima ključnu ulogu $u$ usvajanju stavova i vještina koji omogućuju razvoj tolerancije i poštovanja s obzirom na raznolikost kultura i religija.

Ključne riječi: vjeronaučna didaktika, međureligijska i međukulturna kompetencija, sloboda vjeroispovijesti, mir, solidarnost, bratstvo. 


\section{UvOD}

Nakon razdoblja migrantske krize na europskom se tlu pojavljuje novo žarište kriza i razdora. Ono je potaknuto pandemijskim zbivanjima u kojima se novi svjetski poredak preslaguje oko sve moćnijeg Istoka i sve slabijeg Zapada. Suočeno s posljedicama pandemije čovječanstvo na globalnoj razini ulazi u novu sferu društvenih i ekonomskih odnosa. U njima se mijenjaju uobičajene navike $u$ ophođenju i komuniciranju, poučavanju i učenju, blizini i distanci. Pandemija je prouzročila distancu od svega onoga poznatog i uobičajenog u komunikaciji i zajedničkom življenju. Na europskom je tlu pandemija prouzročila promjenu retorike o međusobnom prihvaćanju, razumijevanju, toleranciji i suživotu koji se nalaze u zasadama europskog društva ${ }^{1}$. Umjesto toga potaknute su i razotkrivene društvene podjele između bogatijih i siromašnijih zemalja, oslabjelo je jedinstvo između zemalja Europske unije u pogledu solidarnosti i zajedništva. Podjele oko dostupnosti i prioriteta cijepljenja još više produbljuju jaz među europskim narodima, ali i na globalnoj razini. Zbog toga se diljem svijeta, a osobito u Europi, produbljuje strah i nesnošljivost među pojedincima i narodima koji se dijele s obzirom na dostupnost cjepiva i prava na cijepljenje, na slobodu kretanja, na slobodu rada i komuniciranja. Mnogi prosvjednici diljem svijeta odbacuju takve podjele i raslojavanja, smatrajući ih zadiranjem u ljudska prava. O tom fenomenu raslojavanja govori i papa Franjo u enciklici Fratelli tutti, u br 18: "Neki dijelovi ljudske obitelji, čini se, mogu biti spremno žrtvovani za potrebe drugih koji se smatraju vrijednima bezbrižnog postojanja ${ }^{2} . "$

U vrtlogu tih promjena vjerski je odgoj izazvan promišljati o resursima koje može ponuditi za kvalitetan i dobar suživot svima, promatrajući antropološke zasade čovjeka. Kao integralni dio suvremene holističke odgojne paradigme, vjerski je odgoj posebice prikladan pružiti potporu miru u svijetu i razumijevanju među narodima, religijama i kulturama. Upravo nasuprot toj težnji prema podjelama, cilj vjeronaučne nastave kao sastavnog dijela međukulturnoga i međureligijskog obrazovanja jest osposobiti učenike da se odgo-

$1 \quad$ Usp. Parlamentarna skupština Vijeća Europe, Preporuka 1962: Religijska dimenzija interkulturnoga dijaloga, 2011., br 7. Usp.: https://rm.coe. int/09000016805d5d56 (26. 12. 2020.).

2 Papa Franjo, Fratelli tutti. Enciklika o bratstvu i socijalnom prijateljstvu. KS, Zagreb 2020., Dokumenti 187.http://www.vatican.va/content/francesco/en/ encyclicals/documents/papa-francesco_20201003_enciclica-fratelli-tutti.html (27. 12. 2020.). 
vorno odnose prema sebi i drugima ${ }^{3}$, prema svijetu koji ih okružuje te „da steknu znanje i razumijevanje njezinih evanđeoskih temelja i katoličkoga nauka, odnosa i nauka Katoličke Crkve prema drugim konfesijama, religijama i svjetonazorima" ${ }^{4}$. Iz tih je razloga i Vijeće Europe uvrstilo religijsko obrazovanje u okvir međukulturnog obrazovanja jer ono pridonosi promicanju tolerancije, međusobnog povjerenja i razumijevanja, poticanju mira, dijaloga i solidarnosti kao i razvoju kulture zajedničkog života ${ }^{5}$.

Naime, nerijetko se u pojedincima i društvu snažno osjećaju i eskaliraju tragovi konflikata i sukoba među etničkim skupinama, religijama i kulturama. Zbog toga je cjelokupni obrazovni sustav prepoznao religijsku nastavu kao sastavni dio interkulturalnog obrazovanja kojim se potiče razvoj senzibiliteta za druge i drugačije te za sjecanje znanja o drugim religijama i svjetonazorima, jer je nepoznavanje drugoga izvor brojnih nesporazuma, predrasuda, a često i sukoba. Da bi se učenici mogli zauzeti za pitanje mira, solidarnosti i bratstva među različitim religijama i kulturama, potrebno je izgrađivati kompetenciju koja omogućuje kvalitetan suživot svih ${ }^{6}$, a koju u ovom radu nazivamo međureligijskom ${ }^{7} \mathrm{i} /$ ili transreligijskom, ukoliko se $\mathrm{s}$ njezinim usvajanjem ipak u zajedničkom kontaktu svi mijenjaju ${ }^{8}$. Nerijetko ona započinje $s$ liječenjem bolnih sjećanja i dubokih rana koje su posljedica starih sukoba ili čak ratova kao što je to slučaj na našim prostorima, posljedica etničke netolerancije i isključivanja drugoga i drugačijega. Pandemija je taj proces

3 Hans Mendl, Der fremde Andere. Praktische Konturen einer Differenzhermeneutik, u: Jahrbuch für konstruktivistische Religionsdidaktik 8 (2018), 106-118.

4 https://narodne-novine.nn.hr/clanci/sluzbeni/2019_01_10_216.html (23. 12. 2020.).

$5 \quad$ Usp. Preporuka Odbora ministara državama članicama o dimenziji religijskih $i$ nereligijskih uvjerenja unutar interkulturnoga obrazovanja,1720, 2008. Usp.: http://assembly.coe.int/nw/xml/XRef/Xref-XML2HTML-en.asp?fileid=17373 (26. 12. 2020.).

6 Iz tog su razloga vjeronaučni programi, osobito na hrvatskom i njemačkom govornom području, podijeljeni na procesno i sadržajno usmjerena kompetencijska područja. Usp. www.nku.hbk.hr/planovi-i-programi/, www.schulamt.at, www. bildungsplaene-bw.de.

7 Usp. Mirjam Schambeck, Interreligiöse Kompetenz: Basiswissen für Studium, Ausbildung und Beruf, Göttingen 2013; Friedrich Schweitzer, Interreligiöse Bildung: Religiöse Vielfalt als religionspädagogische Herausforderung und Chance, Gütersloh 2014.; Stephan Leimgruber, Interreligiöses Lernen, München 2007.

8 Bitni elementi ovog poglavlja kao i tumačenja pojmova potječu iz: Martina Kraml, Religionspädagogik im Kontext der Rede von ,transreligiös', ,transversal ' und ,interreligiös'. Eine möglichkeitsbewusste Erkundung, u: Zekirija Sejdini (ur.): Islam in Europa. Begegnungen, Konflikte und Lösungen. Waxmann Verlag (Münster/New York/München/Berlin) 2018., 175-195. 
učinila još vidljivijim, budući je tijekom prvoga, drugoga i trećega vala zatvaranja sveg društvenog i gospodarskog života u Europi, tzv. lock downa, proširena nova podjela: na one koji su pripadnici određene nacionalne države i one koji to nisu, na zdrave i zaražene, na cijepljene i necijepljene, na građane unutar Europske unije i one izvan nje i slično. Da bi se nadišle podjele i sukobi, čini se da je više nego ikad prije potrebno ustrajati na izgradnji putova za promicanja dijaloga $^{9}$, razumijevanja i sklada, uspostave mira i društvene kohezije ${ }^{10}$. U pogledu međureligijskog dijaloga ne preostaje drugačiji put od međusobnog razumijevanja, tolerancije i izgradnje zajedništva. U tu svrhu međureligijska kompetencija i međureligijski procesi učenja kao i elementi i izazovi današnjeg vremena od velikog su značenja za relevantnost vjeronauka u društvu u pogledu mira i socijalne kohezije.

Upravo se na te dijaloške procese učenja fokusira ovaj rad $u$ drugom poglavlju, u kojem se prezentiraju kriteriji i elementi međureligijske kompetencije u sustavu današnjeg obrazovanja. Naime, prema mišljenju sociologa iz Jene Hartmuta Rose proces obrazovanja vrlo je složen i zatjevan, te se ne može svesti na puko stjecanje kompetencija, već se u njemu radi o procesu u kojem subjekt, tj. učenik stupa u odnos sa svijetom oko sebe i sa svjetovima $u$ sebi, koji je „u najboljem slučaju polu-dostupan”11. Dakle, čak i uz najintenzivnije didaktičke napore, nemamo ga u svojim rukama, ne možemo proizvesti da se dogodi trenutak spoznaje. Ta fragmentarnost procesa obrazovanja posebno se odnosi na sve napore za stjecanje među/transreligijskih kompetencija, a osobito u kriznim vremenima. Naime, obrazovna paradigma usmjerena na kompetencije u obrazovnom kontekstu ponajprije je posljedica pokušaja postizanja mjerljivosti, uspoređivanja i vrednovanja obrazovnih procesa, a ne prvenstveno proces „stupanja u rezonanciju” koji je opisao

$9 \quad$ Dijalog je jedna od ključnih tema enciklike Fratelli tutti te ju Papa suprotstavlja raspravama na društvenim mrežama. U broju 200 tako piše: “Često se dijalog brka s nečim poprilično drugačijim: vatrenim razmjenama mišljenja na društvenim mrežama, često temeljenima na medijskim informacijama koje nisu uvijek pouzdane. Te rasprave su obični paralelni monolozi. Mogu privući određenu pažnju svojim oštrim i agresivnim tonom, ali monolozi ne uključuju nikoga te su najčešće kontradiktorni i služe sami sebi." Usp. http://www.vatican.va/content/ francesco/de/encyclicals/documents/papa-francesco_20201003_enciclica-fratelli-tutti.html (26. 12. 2020.).

10 Usp. Završna deklaracija Europske konferencije o Religijskoj dimenziji interkulturalnog dijaloga, br. 8. Usp. https://rm.coe.int/09000016805d5d56 (26. 12. 2020.).

11 Hartmut Rosa, Resonanz. Eine Soziologie der Weltbeziehung, Suhrkamp, Berlin 2019., 79. 
H. Rosa ${ }^{12}$. Ipak, u ovom ćemo radu propitati mogućnosti razvoja međureligijske kompetencije u kontekstu suvremenog društva koje se snažno mijenja i čija je koherentnost ugrožena, u kojem religije ponovno dobivaju šansu da budu važni akteri na društvenom polju, a osobito u pitanju mira i pomirenja. Radi toga ćemo se u prvom koraku usredotočiti na ključne pojmove i koncepte vezane uz među/ transreligioznu kompetenciju. Nakon toga ćemo s religijskodidaktičkog stajališta ${ }^{13}$ predstaviti elemente međureligijske kompetencije. U trećem, završnom, dijelu pokušat ćemo proširiti horizonte istraživanja i sadržaja međureligijske kompetencije.

\section{1. ŠTO SVE OBUHVAĆA MEĐURELIGIJSKA KOMPETENCIJA?}

Pojam „kompetencija“ najčešće se definira prema F. E. Weinertu, i to kao skup sposobnosti i postignuća koje individuum posjeduje i može kognitivno naučiti kako bi riješio određene probleme, kao i s njima povezane motivacijske, voljne i društvene sposobnosti i spremnosti da bi rješenja problema u različitim situacijama uspješno i odgovorno mogao koristiti ${ }^{14}$. Autori se uglavnom slažu oko ove definicije, jer ona obuhvaća ne samo znanja i vještine nego i motivaciju. No kad se govori o međureligijskoj kompetenciji, onda je važno razjasniti osnovne pojmove jer oni različito prikrivaju i/ ili otkrivaju različite procese ostvarenja zajedništva, a to su: višereigijska, međureligijska i transreligijska kompetencija. Tako se u religijskopedagoškom smislu pojam višereligijski ${ }^{15}$ odnosi na obrazovanje i učenje u kontekstu različitih religija, koje često koegzistiraju bez značajne interakcije i zajedničkog učenja ili nastojanja za zajedništvom. Stoga je pojam „međureligijski“ točniji u kontekstu nastojanja oko obrazovanja i zajedničkog učenja, jer se više usredotočuje na ono što je zajedničko, a posebno na zajedničko učenje. U tom smislu, međureligijski obrazovni procesi trebaju biti osmišljeni na način da je fokus na susretima, približavanju jednih drugima, upoznavanju stajališta drugih, kao i učenje s drugima i jedni od drugih. Pritom cilj nije zamagliti razlike, nego ih poštovati i priznati. Upravo međureligijsko učenje traži načine i modele koji omo-

12 Usp. Isto, 78.

13 U ovom radu najviše se koristimo djelima Hansa Mendla, osobito Hans Mendl, Religionsdidaktik kompakt, Kösel, München, 2018.

14 Franz Weinert, Concept of competence. A conceptual clarification, u: Dominique S. Rychen - Laura H. Salganik (ur.), Defining and selecting key competencies, Hogrefe \& Huber Publishers, 2001., 45-65.

15 Usp. Martina Kraml - Zekirija Sejdini (ur.), Interreligiöse Bildungsprozesse: Empirische Einblicke in Schul- und Hochschulkontexte, Stuttgart, 2018. 
gućuju zajedničko učenje unatoč razlikama. Ipak, klasični pojam „međureligijski”, koji se odnosi na dijalog između nekoliko različitih religija i koristi se za „međureligijski” dijalog, sve se više kritizira u migracijskoj pedagogiji ${ }^{16}$. Terminologija koja se koristi za interkulturalno obrazovanje u europskim zemljama je različita. U Hrvatskoj primjerice u vjeronauku prevladavaju pojmovi „međureligijska i međukulturna raznolikost, upoznavanje, tolerancija i dijalog“, dok $\mathrm{u}$ austrijskim vjeronaučnim programima prevladavaju pojmovi kao „priznavanje i raznovrsnost religija, tolerancija i vrednovanje raznovrsnosti kultura, religija i svjetonazora“. U Njemačkoj prevladavaju pojmovi „međukulturni i međureligijski dijalog, prevladavanje predrasuda i sukoba, razumijevanje među svjetskim religijama“ itd. ${ }^{17}$.

U pedagoško-kulturnim kontekstima njemačkoga govornog područja koristi se i pojam „međukulturni”, iako prefiks „među” izaziva sve više kritika, budući da samo po sebi ne zahtijeva snažnu toleranciju obiju strana, već je u pogledu moći manje zastupljena religija ili kultura u opasnosti da se asimilira i nestane. Iz tog razloga pojam „transkulturalan” sve se češće koristi u posljednjih nekoliko godina jer se nastoji distancirati od klasičnog koncepta kulture, budući da potonji izaziva konotacije kao što su izolacija, homogenost i esencijalizam ${ }^{18}$. Iz tog se razloga prema M. Kraml, u kontekstu multireligioznog društva s migrantskom pozadinom, pojam „transreligijski" percipira kao prikladniji, budući da uključuje individualne i kolektivne interese, odnose između blizine i udaljenosti te međuovisnost. "Kada koristimo izraz ,transreligijski', možemo razlikovati tri značenja: Traženje veza izvan postojećih religija, npr. traženjem veza između religija u duhovnom ili mističnom smislu; traženje zajedničkih obilježja koja su prisutna u svim ili u određenim religijama, npr. odgovornost za zemlju i ljude i prijenos s jednog religioznog područja tradicije na drugo." 19 .

16 Paul Mecheril, Einführung in die Migrationspädagogik, Weinheim,Basel, Beltz 2004. Također više o autoru i njegovim istraživanjima na: https://www.unisiegen.de/zlb/weiterbildung/ment4you/documents_rv_wise201920/mecheril_2016_migrationspaedagogik_ein_projekt.pdf (27. 12. 2020.).

17 Usp. https://religobraz.wordpress.com/ (26.12.2020.), također: www.nku.hbk. hr/planovi-i-programi/, www.schulamt.at, www.bildungsplaene-bw.de (23. 3. 2021.).

18 Kraml napominje da pojam potječe iz vremena razvoja međureligijske teologije i filozofije, kada su njihovi začetnici bili Karl Baier i Roland Faber. Usp Roland Faber, Der transreligiöse Diskurs', u: Polylog. Zeitschrift für interkulturelles Philosophieren 9 (2003.), str. 65-94. Također: https://homepage.univie.ac.at/ karl.baier/texte/pdf/TransreligioeseTheorie.pdf (23. 12. 2020.).

19 Martina Kraml, Religionspädagogik im Kontext der Rede von ,transreligiös', ,transversal ' und ,interreligiös'. Eine möglichkeitsbewusste Erkundung, u: Zekirija 
Međutim, pojam „transreligiozan” ne uključuje nužno kritičko ispitivanje kategorije razlikovanja i ne iziskuje otkrivanje potencijala za nasilje jedne religije protiv druge. Stoga ga, prema Kraml, treba koristiti zajedno s pojmom „transverzalan”, koji pretpostavlja tendenciju prema svijetu heterogenosti i raznolikosti, u kojem treba uspostaviti veze, treba stvoriti mostove i prijelaze. U svom obraćanju Vijeću Europe papa Franjo ide $u$ istom smjeru kada govori o potrebi transverzalne komunikacije: „Kada bismo danas željeli opisati kontinent, trebali bismo govoriti o Europi koja je u dijalogu, osiguravajući da transverzalnost mišljenja i razmišljanja čuva skladno ujedinjene narode. [...] Jer u sadašnjem političkom svijetu Europe dijalog, koji se odvija samo unutar vlastitih (političkih, vjerskih, kulturnih) organizama, se dokazuje neplodnim“20.

Transverzalna perspektiva primjenjuje se u superviziji, $u$ integrativnom terapeutskom pristupu, ali i u znanstveno-teorijskom području komparativne religijske pedagogije. Prema M. Kraml ${ }^{21}$ transreligiozna ili još bolje transverzalna perspektiva omogućuje identifikaciju i rješenje zajedničkih problema koji prožimaju religije, percepciju podjela moći i tamnih strana, kao i kritičko razmišljanje o vlastitim i stranim obilježjima, razlikama i sustavima razlike s obzirom na njihove učinke i posljedice. Oba termina - transreligijski i transverzalan - mogu sadržavati kritični potencijal koji pomaže jasno vidjeti strukture moći i stvoriti novu osnovu za zajedništvo. Istodobno, međutim, Kraml upozorava da se ovi pojmovi, kao što su „transkulturalan, transreligiozan ili transverzalan”, zbog svog potencijala za tranziciju i prijelaz mogu koristiti u pozitivnom smislu, ali da se $u$ isti mah ne smije iz vida ispustiti njihov potencijal za brisanjem i zamračivanjem hijerarhija i razlike. Stoga je važno držati budnim pitanje pronalaženja prave ravnoteže u uporabi ovih

Sejdini (ur.): Islam in Europa. Begegnungen, Konflikte und Lösungen. Waxmann Verlag (Münster/New York/München/Berlin) 2018., posebno 179-185, ovdje 184.

Vidi cijeli govor pape Franje pred Vijećem Europe 25. 11. 2014., na: http:// www.vatican.va/content/francesco/de/speeches/2014/november/documents/ papa-francesco_20141125_strasburgo-consiglio-europa.html (23. 12. 2020.). Također o dijalogu usp. Klara Ćavar - Vikica Vujica, Odgoj za dijalog kao preduvjet mira. Kršćanska perspektiva odgoja za dijalog, u: Magistra Iadertina (13) 2018, 51-68. Također usp. Ružica Razum, Odgojno djelovanje suvremene škole: izazovi i mogućnosti za religiozni odgoj. Bogoslovska smotra, 77 (2007),4, str. 857-880. Također usp: Ivan Šarčević, Međureligijski dijalog pred alternativom vjere i nevjere. U povodu 30. obljetnice Asiškoga međureligijskoga susreta. Služba Božja, 57, (2017)., 1: 7-23.

21 Usp. Zekirija Sejdini, Martina Kraml, Matthias Scharer, Mensch werden. Grundlagen einer interreligiösen Religionspädagogik und-didaktik aus muslimisch-christlicher Perspektive (Studien zur Interreligiösen Religionspädagogik 1), Kohlhamme, Stutgart, 2017. 
pojmova u pogledu razlika te njihove uvjetovanosti. Tako se pojam „višereligijski” odnosi na postojanje različitih svjetonazora i religija jednih pored drugih bez dodira. Pojam „međureligijski”, iako naglašava zajedničko, može probuditi ideju naoko homogenih (vjerskih) struktura koje se samo djelomično dodiruju i preklapaju. Prema Kraml, Sejdini i Schareru ${ }^{22}$ pojmovi „transreligijski” i „transverzalni” sadrže aspekt da je javni kontekst onaj kojem su sve religije i uvjerenja upućeni i u kojem se susreću. Upravo kroz susret dolazi do stvaranja novoga kulturnog prostora u smislu teorije indijskoameričkog književnika i filozofa Homija K. Bhabhe, koji to susretanje naziva „treći prostor”, otvoreno mjesto za transreligijske susrete. ${ }^{23}$ „U njemu se mijenja subjekt, postaje subjekt u susretu, čvorište, raskrižje govora, diskursa, sistema. Bhabha smatra da su kulture porozne, da postoji nešto poput mimikrije $u$ kulturama te da se nikada ne susreću originali, nego samo interpretacije religioznosti. Original se nalazi u dubini, u središtu, te se kao takav i sam nadopunjuje u procesu transkulturalnosti. Treći prostori nisu specifična mjesta, već procesi razmjene između stranoga i vlastitog. U trećem prostoru mijenjamo perspektivu; tek kad smo svjesni tuđe, možemo o svojoj produktivno promišljati i premještati perspektive tako da uvijek ostane neki slobodni ostatak, koji se otvara kao produktivni treći prostor“ 24 .

22 Usp. Martina Kraml - Zekirija Sejdini, Konflikte und Konfliktpotentiale in interreligiösen Bildungsprozessen: Empirisch begleitete Grenzgänge zwischen Schule und Universität (Studien zur Interreligiösen Religionspädagogik 3), Kohlhammer, Stuttgart, 2020.

23 Bhabhaova razmišljanja o kulturnoj razlici i "kulturnom prijevodu" dovode do koncepta hibridnosti i time do Bhabhinog koncepta trećeg prostora. Izrazom mimikrija, koji potječe iz biologije, Bhabha opisuje zaštitni mehanizam ljudi iz slabije kulture da se djelomično prilagode. Na vjerskoj razini, on misli na situacije iz dijaspore $\mathrm{u}$ kojima se muslimani danas nalaze $\mathrm{u}$ mnogim europskim zemljama ili kršćani na Bliskom istoku ili u Indiji. Kroz kulturnu ili vjersku kamuflažu potlačena stranka dobiva s jedne strane prostor za manevar, a, s druge strane, u međuprostoru se otvara mogućnost za otpor. Za kolonizirane, ova strategija može značiti opstanak i omogućiti sigurnost. Kolonizirani pokušava poslušati svog kolonizatora tako što se ponaša kao ovaj potonji. To je, međutim, uvijek neka vrsta kompromitirajuće farse, jer ni kolonizirani ni kolonizator ne žele biti promijenjeni i potlačeni na bilo koji način od strane drugog. Usp. Matthias Scharer, "Third Spaces" - Räume für die interreligiöse Begegnung an "generativen" Themen. Gewaltprävention durch Themenzentrierte Interaktion nach Ruth C. Cohn, u: Monika Datterl - Wilhelm Guggenberger - Claudia Paganini (ur.), Gewalt im Namen Gottes - ein bleibendes Problem?, Innsbruck, 2017., 71-90. Također: Matthias Scharer, TZI als Third Space transreligiöser Begegnungen, u: Themenzentrierte Interaktion 31, (2017.) 2, 131-138, ovdje 136 i dalje.

24 Jadranka Garmaz - Jozef Stala, Neki elementi $i$ načela konfesionalno suradničkog vjeronauka, u: Crkva u svijetu 54 (2019.) 1, 42-58, ovdje 45-46. 
Stoga pojam međureligijskih i transreligijskih kompetencija obuhvaća sve što Franz Weinert razumije po definiciji kompetenci$\mathrm{ja}^{25}$; ipak, transreligijske kompetencije nisu samo „vještine i sposobnosti za rješavanje određenih problema" nego se, prema Helmutu Peukertu, odnose „na stav prema drugome i usmjerene su na prepoznavanje i razumijevanje drugoga" ${ }^{26}$. Peukert podržava koncept obrazovanja koji se temelji na dijalogu s drugima. Sličan pogled na obrazovanje, ali s obzirom na vjersko obrazovanje, zagovara $\mathrm{R}$. Englert. Njegova se istraživanja temelje tezi da je vjersko obrazovanje „pogled na svijet iz perspektive pripadnosti religiji” i da pripadanje samo po sebi znači dinamičan proces ,jačanja, intelektualnog prosvjetljenja i pojašnjenja u vezi s vlastitom religijom, kao i otvorenosti i suradnje s drugim religijama" 27 . Na temelju dugogodišnjeg istraživanja religijskog obrazovanja R. Englert je mišljenja da samo konfesionalni vjeronauk koji je u svojoj provedbi otvoren i dijaloški može odgovoriti na potrebe današnjeg društva u smislu „učenja iz religije” te kao takav ima budućnost u školama. Međutim, to učenje se ne događa ekskluzivistički, nego ekumenskom suradnjom i međureligijskom razmjenom. Međusobna konfesionalna suradnja i međureligijsko učenje temelji su vjerskog ili međureligijskog učenja ${ }^{28}$, za što se zalaže i Meyer. On pod međureligijskim učenjem podrazumijeva „namjerno kontrolirane, pedagoške procese u kojima se otvaraju prostori za susrete s vjerskim svjedočanstvima, čija se vjerska pozadina konstituira drugačije od onog učenika [ili značajnog dijela skupine za učenje], a koji su osmišljeni tako da se temelje na konstruktivnoj raspravi i poštovanju ostalih učenika“"29. Prema Meyeru, ali sukladno i drugim relevantnim autorima za ovu temu, kao što je freiburška religijska pedagoginja Mirjam Schambeck ${ }^{30}$, ključno je za

25 Usp. Franz Weinert, Concept of competence: A conceptual clarification, u: Dominique S. Rychen - Laura H. Salganik (ur.), Defining and selecting key competencies, Hogrefe \& Huber Publishers, 2001., 45-65.

26 Peukert, Helmut, Bildung als Wahrnehmung des Anderen. Der Dialog im Bildungsdenken der Moderne, u: Ingrid Lohmann, Weiße, Wolfram (ur), Dialog zwischen den Kulturen. Erziehungshistorische und religionspädagogische Gesichtspunkte interkultureller Bildung, Münster 1994., 1-14, ovdje 11.

27 Usp. Hans Georg Ziebertz - Ulrich Riegel, Letzte Sicherheiten. Eine empirische Untersuchung zu Weltbildern Jugendlicher, Gütersloch, 2008. (Religionspaedagogik in pluraler Gesellschaft 11).

28 http://www.zdk.de/veroeffentlichungen/erklaerungen/detail/Fuer-einenzukunftsfaehigen-Religionsunterricht-konfessionellkooperativ-dialogisch-240Q/ (10. 04. 2018.). Für einen zukunftsfähigen Religionsunterricht konfesionell, kooperativ, dialogisch. Beschlossen von der Vollversammlung des ZdK am 6. 5. 2017

29 Karlo Meyer, Grundlagen interreligiösen Lernens, Vandenhoeck \& Ruprecht, Goettingen, 2019., 69.

30 Usp. Isto, str. 28-32. 
međureligijsku kompetencije da netko „ima sposobnost da razluči vlastitu religiju od svoje (kompetencija razlikovanja) te da se istodobno stupi u odnos s drugim (kompetencija uspostavljanja odnosa). Međureligijska kompetencija tada zahtijeva sposobnost da se izričito uključi vjerska raznolikost u vlastito pozicioniranje religije“31. To otkriva drugu temeljnu definiciju međureligijske kompetencije. Prema M. Schambeck ${ }^{32}$ ona obuhvaća tri područja: kao prvo, uključuje estetsko područje kompetencije da se mogu uočavati različiti oblici vlastitih i drugih religija. Drugo, međureligijska kompetencija razvija se kao hermeneutičko-refleksivna i komunikativna kompetencija, u smislu razumijevanja i sposobnosti izražavanja sadržaja vlastite religije pred drugom religijom. Treće i konačno, obuhvaća praktično područje kompetencije koje se, s jedne strane, dokazuje kao praktični kapacitet za razmišljanje, to jest sposobnost odgovora na pitanja koja postavlja raznovrsnost religija. S druge strane, praktično područje može se shvatiti kao kapacitet za oblikovanje života. Međureligijska kompetencija razvija se kroz interakciju između ljudi koji promiču različite vjerske tradicije. S jedne strane, to je povezano $\mathrm{S}$ činjenicom da pojam kompetencije sam po sebi opisuje sposobnosti i vještine ljudi te se stoga može shvatiti kao osobna karakteristika. Međutim, kompetencija se odnosi na prostor interakcije religijske tradicije, shvaćen kao njezin sociokulturni oblik, kao sadržaj za razmišljanje i tumačenje. Odatle se postavljaju pitanja u vezi s drugim vjerskim tradicijama.

Međureligijska kompetencija pretpostavlja procese u kojima se događa međureligijsko učenje i obrazovne procese koji na odgovarajući način dovode religiju u jezik. To s jedne strane znači da će se u njima religiju shvatiti ozbiljno kao višeznačan fenomen, a s druge strane, kao što je gore navedeno, religije drugih ljudi i zajednica se ne mogu učiti samo iz sadržaja već se potpuno mogu usvojiti tek u autentičnim situacijama susreta s drugima.

31 Odgovorni pedagoški proces učenja također uključuje poticanje učenika na traženje vjerskog identiteta unutar vlastitoga vjerskog i kulturnog horizonta, kao i na spremnost i sposobnost komunikacije sa stranim denominacijskim i vjerskim usmjerenjima (https://www.bibelwissenschaft.de/wirelex/das-wissenschaftlichreligionspaedagogische-lexikon/wirelex/sachwort/anzeigen/details/interreligioeses-lernen/ch/c3c1e49333faa45ad6c84eb70f105c88/,19_8_2020).

32 Usp. Mirjam Schambeck, Nachholbedarf im Umgang mit Fremden. Überlegungen zur interreligiösen Kompetenz, u: Herder Korrespondenz, Bildung, 1 (2014.), str. 28-32, ovdje 30-32. 


\section{NEKA NAČELA I KRITERIJI MEĐURELIGIJSKE KOMPETENCIJE U VJERONAUKU}

Kompetencije su prema Weinertu ${ }^{33}$ kognitivne sposobnosti i vještine koje se mogu naučiti kako bi se riješili određeni problemi, kao i povezane motivacijske, voljne i socijalne spremnosti i sposobnosti kako bi se mogle uspješno i odgovorno koristiti u različitim situacijama. Pojedinačna kompetencija obuhvaća aspekte koji međusobno djeluju poput mreže, poput znanja, sposobnosti, razumijevanja, sposobnosti, akcije, iskustva i motivacije, koji omogućuju osobi da se nosi sa specifičnim situacijama zahtjeva određene vrste. Dimenzije vjerske kompetencije u vjeronauku u školama obuhvaćaju sveobuhvatno obrazovno znanje, sposobnost izražavanja vlastite vjere, aktivnost u vjerskoj zajednici, razvoj vještina komunikacije i vjerski motiviranog načina života ${ }^{34}$.

Vjeronaučna didaktika ${ }^{35}$ fokusira pitanje uspješnog učenja i poučavanja u kontekstu religije. Budući da se nalazimo u kontekstu globalizacije u kojem se isprepleću razne religije, zbog čega je potrebno pored svoje poznavati i religiju drugoga, s njom surađivati i međusobno se zauzimati za bolji svijet, međureligijska kompetencija čini se neizbježno potrebnom. Iz tog su razloga i vjeronaučni programi, osobito na hrvatskom i njemačkom govornom području, podijeljeni na procesno i sadržajno usmjerena kompetencijska područja. Na taj način omogućuju usvajanje religijskih sadržaja i pokreću procese suradnje i dijaloga. Iz tog razloga u vjeronaučnim programima njemačkoga i hrvatskog govornog područja postoji pet procesno usmjerenih kompetencijskih područja: percepcija izražena u glagolima spoznati i opisati, spoznaja izražena u glagolima razumjeti i tumačiti, performansa izražena u glagolima urediti i djelovati, interakcija izražena u glagolima komunicirati i prosuđivati te participacija izražena glagolom sudjelovati. U isti mah su sadržajno usmjerena kompetencijska područja sljedeća: čovjek i njegovo životno okruženje, življena religija i ona o kojoj se uči, religioznost u društvu i kulturi, kao i religiozna i svjetonazorska raznolikost.

Kombiniranjem procesnih i sadržajnih kompetencijskih područja osiguravaju se dimenzije religiozne kompetencije u području znanja, vještina i stavova. One obuhvaćaju obrazovno znanje u sveobuhvatnom smislu, tj. znanje kao orijentacijsku veličinu za osobno tumačenje svijeta i kao motivaciju za doživotno sučeljavanje s reli-

33 Usp. bilješku 27 i 28.

34 Usp. Hans, Mendl, Religionsdidaktik kompakt, Kösel, München, 238-239.

35 Usp. Jadranka Garmaz, Sadržajni aspekti didaktike školskog vjeronauka, u: Crkva u svijetu 40, br. 3. (2005.), 279-302. 
gioznim sadržajima, zatim sposobnost izražavanja vlastitih religioznih sposobnosti i nadarenosti, sposobnost aktiviranja u religioznoj zajednici, sposobnost za izgradnju religiozne komunikacijske sposobnosti te osobno religiozno motivirano oblikovanje života ${ }^{36}$. Budući da se u religijskoj kompetenciji religioznost, religijska i svjetonazorska raznolikost nalaze u samom središtu interesa, međureligijska je kompetencija prisutna u gotovo svim europskim kurikulima ${ }^{37}$.

Međureligijsko učenje zahtijeva prostore u kojima bi se usvajale dimenzije vjerskih kompetencija različitih religija. Ono traži prostor za susrete $\mathrm{s}$ vjerskim svjedočanstvima drugih religija, kao i njihovo konstruktivno ispitivanje i sučeljavanje s njima, kako bi se stekle međureligijske vještine. Na koji način se stječe međureligijska kompetencija dijelom je poznato iz relevantnih vjeronaučnih didaktika autora kao što su Hilger ${ }^{38}$, Leimgruber, Mendl i drugi. Stephan Leimgruber ${ }^{39}$ je još 2007. imenovao pet koraka međureligijskog učenja koji vode do usvajanja međureligijske kompetencije: religijska senzibilnost za osobnu religiju i za religiju drugoga, tumačenje religijskih fenomena, učenje kroz susret, prihvaćanje trajne stranosti i međusobno sučeljavanje. Iz toga se mogu sintetizirati središnja načela međureligijskog učenja ${ }^{40}$ : personalizacija kao stvarni ili medijski, tj. virtualni susret s ljudima koji su pripadnici drugih religija, umjesto čisto dogmatskog ispitivanja načela drugih religija izvan konteksta; kontekstualizacija kao bavljenje kulturnim, socijalnim i političkim kontekstima drugih religija, npr. posljedice za suživot $u$ vjerskoj zajednici i u svijetu, život u obitelji, stavovi prema životu i smrti; elementarizacija i učenje o stranim religijama prema načinu "od bliskog do dalekog" - npr. islam započinje najprije iz opipljive blizine, ili židovstvo najprije iz zajedničkih vjerskih korijena judeokršćanske tradicije; usmjerenost na subjekt; osim sposobnosti razlikovanja i povezivanja radi se i o egzistencijalnom pojašnjenju vlastitog odnosa prema religiji kroz percepciju i obradu drugih religija ${ }^{41}$.

36 Usp. Jadranka Garmaz, NOK i vjeronauk: religiozna kompetencija u školskom vjeronauku, u: Crkva u svijetu 47, br. 4 (2012): 427-451.,ovdje 427. Usp. https:// hrcak.srce.hr/94864 (pristup 23.3.2021.)

37 Usp. . Ružica Razum- Marija Jurišić (ur.), Interkulturalnost i religijsko obrazovanje u europskim dokumentima i kurikulumima / Interculturality and Religious Education in European Documents and Curricula, Zagreb 2020., str. 5.

38 Usp. Georg Hilger, Stephan Leimgruber, Hans Georg Ziebertz, Religionsdidaktik. Ein Leitfaden fuer das Studium, Ausbildung und Beruf, München 2001.

39 Usp. Stephan Leimgruber, Interreligiöses Lernen, München 2007.

40 Usp. Hans Mendl, Religionsdidaktik kompakt, Kösel 2011., 131.

41 Mirjam Schambeck, Interreligiöse Kompetenz.Basiswissen für Studium, Ausbildung und Beruf, Göttingen 2013. 
Osim ovih osnovnih načela međureligijskog učenja, postoje kriteriji koje treba poštivati prilikom planiranja procesa vjerskog učenja na polju međureligijskog učenja kako bi učenici razvili stav prema religiji i religijama. To su točno prikazivanje sadržaja i učenja druge religije; otvaranje pitanja i poticanje daljnjih procesa učenja; uključivanje životnog konteksta religije u učenje o njoj; kritičko sučeljavanje sa stranom i vlastitom religijom; ispravljanje predrasuda i očekivanja učenika; promicanje produktivne i kritičke rasprave; primjerenost učeničkoj skupini; provjerljivost sadržajnih činjenica ${ }^{42}$.

Iz spomenutih kriterija nude se sljedeće mogućnosti i putOvi učenja prilikom planiranja međureligijskog učenja: taj se proces može odvijati putem učenja uz pomoć vjerskih predmeta drugih religija; putem učenja na vjerskim mjestima gdje se konkretiziraju druge religije; putem upoznavanja sa specifičnim oblicima življenja i slavljenja i na osobit način osobnim upoznavanjem s pripadnicima drugih religija ${ }^{43}$.

Na taj način međureligijska kompetencija ostvaruje ciljeve koje je zacrtao još Ivan Pavao II. utirući putove međureligijskog dijaloga. Osim mnogih putovanja osobito su znakoviti međureligijski susreti u Asizu 1986. godine, u Rimu 1999. i ponovno u Asizu 2002. „Na svim susretima s predstavnicima drugih religija papa Ivan Pavao II. uvijek je naglašavao potrebu uzajamnoga dijaloga, promicanje zajedničkih vrijednosti i zajedničku zauzetost na društvenom području za dobro čovječanstva"44. Taj proces međusobnog zbližavanja ponovno je intenzivirao papa Franjo hodočašćem u Irak u ožujku 2021., ali i u mnogim međureligijskim susretima, kroz dijalog, uvažavanje i međusobno upoznavanje.

\section{MoguĆnOSTI I GRANICE MEĐURELIGIJSKOG OBRAZOVANJA}

Jenski sociolog Hartmut Rosa tvrdi da se obrazovni procesi, tj. obrazovanje odvijaju ondje gdje postoji odjek, gdje se dogodi živi

42 Clauß Peter Sajak, Interreligiöses Lernen im schulischen Kontext, u: Bernhard Grümme - Hartmut Lenhart, Manfred Pirner, (ur.), Religionsunterricht neu denken. Innovative Ansätze und Perspektiven der Religionsdidaktik, Stuttgart 2012., 223-234.

43 Katechetische Blatter 142 (2017.), Heft 3: Interreligiöse Begegnungen; Langenhorst, Georg, Trialogische Religionspädagogik. Interreligiöses Lernen zwischen Judentum, Christentum und Islam, Freiburg i. Br., 2016; Clauß Peter, Sajak Interreligiöses Lernen, Darmstadt 2018.; Mirjam Schambeck, Interreligiöse Kompetenz. Basiswissen für Studium, Ausbildung und Beruf, Göttingen, 2013.

44 Božidar Nagy, Papa Ivan Pavao II. na velikim međureligijskim skupovima, u: Obnovljeni Život 69, br. 2. (2014.), 221-229, ovdje 221. 
susret čovjeka i njegova svijeta, pri čemu misli na specifičan način na koji se ljudi međusobno odnose i stupaju u odnos s događajima i stvarima. Taj takozvani odnos rezonancije ne može se planirati i treba mu prostor da se prepusti, kao i određeno mjesto na kojem se to može dogoditi: „Rezonancija sadrži trenutak otvorenosti i nedostupnosti koji je razlikuju od kompetencije. Kompetencija znači sigurno ovladavanje tehnikom" 45 ; rezonancija se, s druge strane, odnosi na „proces stupanja u odnos s nekim sadržajem“. To znači da ako dijete ili mlada osoba iznenada otkriju kako ih posebno zanima povijest, ili politika, ili fizika, ili glazba itd., to znači da im oni nešto govore - oni se njih tada posebno tiču. No kada će se pojaviti taj interes i trenutak znatiželje i spoznaje, to ostaje gotovo potpuno nedostupno.

Takav pristup procesu obrazovanja predstavlja svojevrsnu kritiku obrazovnog koncepta koji koči rezonanciju, a kao takav sukladan je, prema M. Schareru, teoriji Ruth C. Cohn, u kojoj ona razlikuje „živo“ učenje od tzv. „mrtvog“ učenja. Matthias Scharer dalje razvija Rosine misli kada kaže: „Živo učenje prema TZI ${ }^{46}$ otvara prostor živih odnosa djece, mladih i njihovih učitelja sa sadržajima koji se trenutno uče u učionici, a odgovor na pitanje o rezonanciji, tj. kairosu učenja uglavnom nije dostupan, što odgovara općenitom teološkom nauku o milosti. U kontekstu školskog učenja ta je rezonancija velik izazov." 47

Ako, slijedeći Rosu, shvaćamo obrazovanje kao proces uspostavljanja odnosa sa sadržajima i s drugima, onda međureligijski obrazovni procesi imaju za cilj produktivni odnos između onoga što je vlastito i onoga što je strano, pri čemu aspekt stranosti ostaje konstitutivni didaktički element o kojem se raspravlja i koji se posebno vrednuje. ${ }^{48}$ Ako je to slučaj, onda je Schambeck u pravu kada tvrdi da je razvoj stavova poniznosti i otvorenosti, dobrohotnosti, priznanja i uvažavanja, spremnosti na promjenu i uspostavljanje prija-

45 Hartmut Rosa, Unverfügbarkeit, 2019.,79.

46 Ruth C. Cohn razvila je koncept učenja i poučavanja te vođenja pod nazivom „interakcija usmjerena na temu“. Više u: Jadranka Garmaz - Matthias Scharer, Učenje vjere. Kako osmisliti i voditi proces učenja vjere? Komunikativnoteološka koncepcija, Zagreb, 2014. Također usporedi službenu stranicu Instituta Ruth C. Cohn u Berlinu na: https://www.ruth-cohn-institute.org/home.html (26. 12. 2020.).

47 Matthias Scharer, Unterrichtsgespräche aus der Perspektive der Themenzentrierten Interaktion und der Kommunikativen Theologie, u: Annegret Reese-Schnitker Daniel Bertram - Dominic Fröhle (ur.), Gespräche im Religionsunterricht. Eine Studie zur unterrichtlichen Praxis mit Anregungen für die Lehrerausbildung, Kohlhammer Verlag 2021.

48 Usp. Hans Mendl, Religionsdidaktik, München 2018., 151-156. 
teljstva ${ }^{49}$ od velike pomoći u stjecanju međureligijske kompetencije. Vratimo li se Rosinim razmišljanjima o obrazovanju kao "procesu koji je usmjeren na uspostavljanje odnosa, tj. na rezonanciju", možemo reći da proces učenja koji se temelji na visokoj toleranciji, igra presudnu ulogu u razvoju međureligijskih kompetencija.

Suvremena religijska pedagogija stoga zahtijeva model kooperativnog vjeronauka u kojem je proces jednako važan kao i rezultat, kao što je umirovljeni bečki religijski pedagog Martin Jäggle rekao u intervjuu: "Priznanje prije svakog postignuća"50. Jäggle je dugogodišnjim istraživanjima pokazao da je kontekstno senzibilna i komparativna religijska pedagogija u svojem istraživačkom usmjerenju ovisna o kontekstu i da tako mora biti želi li ostati relevantnom. On je kao i većina u članku spomenutih autora kritičan prema isključivoj upotrebi izraza „međureligijski“. Iz tog razloga potrebno je imati u vidu da komparativna istraživanja uključuju transverzalnost u smislu prepoznavanja različitih načina života, otvorenosti za promjene i umrežavanja različitih područja i partnerstava u znanosti i učenju ${ }^{51}$.

Prema Schareru takav djelomično moćan vjerski odgoj nužno je politički zainteresiran u smislu preuzimanja odgovornosti u svjesnom bavljenju suvremenim fenomenima (vjerskog) života. Ako pandemiju korone smatramo globalnim fenomenom i problemom, rješenje tog problema također treba tražiti na globalnoj razini. U kontekstu vjeronauka to bi značilo kombinirati različite religije i uključiti ih u potragu za odgovorima na trenutačnu krizu, jer upravo bi vjerske zajednice iz svoje kulturne i filozofske baštine mogle ljudima pružiti svaku moguću potporu (npr. socijalnu potporu, pastoral) u teškim vremenima. Da bi se takva suradnja između različitih religija mogla ostvariti, potrebno je zahtijevati stjecanje međureligijskih / transreligijskih kompetencija i razviti zajednička istraživačka područja.

Dakle, ne postoji recept koji propisuje ili objašnjava određeni postupak, ali postoji uzak prolaz kroz koji se mogu steći fragmentarni elementi međuvjerskih kompetencija, ovisno o tome koji smo put odabrali da do njega dođemo. U vjeronauku, koji se temelji

49 Razmišljanja o vlastitim predrasudama mogu biti korisna. Osobito mogu pomoći stavovi poniznosti i prisebnosti, otvorenosti, dobrohotnosti, priznanja i uvažavanja, spremnosti na promjenu i stvaranja prijateljstava. Usp. Mirjam Schambeck, Interreligiöse Kompetenz: Basiswissen für Studium, Ausbildung und Beruf, Vandenhoeck - Ruprecht, 2013.

50 Usp. Martin Jäggle - Thomas Krobath - Robert Schelander (Hg.), lebens-werteschule. Religiöse Dimensionen in Schulkultur und Schulentwicklung, Wien, 2009., 20, ili Martin Jäggle, Anerkennung vor jeder Leistung. Interview mit Martin Jäggle, u: Das Wort 3 (2008), 4.

51 Usp. https://www.rel-edu.eu/ (26. 12. 2020.) 
na kontekstualnoj teologiji prema Gaudium et spes, put je jednako važan kao i rezultat. Ako sebe doživljavamo kao zajednicu na putu ili, prema Bertu Roebbenu, kao "hodočasničku zajednicu" 52 , tada je put jednako važan kao i odredište. U prenesenom smislu, s obzirom na hodočašćenje možemo ustvrditi da je u procesu stjecanja međureligijskih vještina netko prolazio lijepom stazom, drugi strmom, dok se treći probijao kroz gustiš. Sukladno tome, put do stjecanja međureligijskih kompetencija ovisi ne samo o zemljopisnom nego i o povijesnom reljefu nacije i zajednice ili o biografskom iskustvu obitelji i pojedinaca ${ }^{53}$. Ovo iskustvo i put osobe, zajednice i nacije sveto je tlo nepoznatih, pojedinačnih i kolektivnih iskustava i sjećanja koja se mogu samo djelomično razumjeti i iz kojih se prvenstveno treba učiti ${ }^{54}$.

Iz svih navedenih razloga možemo ustvrditi da međureligijska kompetencija otvara prostore dijaloga i suradnje koji mogu pomoći da se zajedno prebrode krizna vremena, da se otvore tako željeni prostori za susrete ${ }^{55}$ i prepoznavanje drugih kao braće ${ }^{56}$ te da se shvati kako geste ljubavi mogu preokrenuti osobnu i društvenu povijest ${ }^{57}$.

\section{ZAKLJUČAK}

U kontekstu suvremenih društvenih, kulturnih, ekonomskih i religijskih podjela međureligijska kompetencija postaje neizostavan

52 Usp. Bert Roebben, Religionspädagogik der Hoffnung. Grundlinien religiöser Bildung in der Spätmoderne, Münster, LIT 2011., 83-94, ovdje 93.

53 Isto, str. 92.

54 Cilj međukulturnog i međureligijskog obrazovanja u Europi, kojeg je vjeronauk sastavni dio, upravo je postizanje senzibilnosti, tolerancije i ispravnog vrednovanja raznovrsnosti kultura i religija kao i različitih svjetonazora, susret s njima i stvaranje novih načina pravednog suživota, mira i društvene kohezije. Usp. www. nku.hbk.hr/planovi-i-programi/, www.schulamt.at, www.curriculumonline.ie, www.snalsbrindisi.it, www.bildungsplaene-bw.de itd.

55 O teološkim, posebice biblijskim temeljima pomirenja i mirotvorstva, a koji su od presudne važnosti za usvajanje međureligijske kompetencije na našim prostorima može se pronaći u nagrađivanoj knjizi evangeličkog teologa Miroslava Volfa, Exclusion and Embrace. A Theological Exploration of Identity, Otherness and Reconciliiation. Nashville, Abingdon, 1996. Knjiga je prevedena i na hrvatski: Miroslav Volf, Isključenje i zagrljaj. Teološko promišljanje identiteta, drugosti i pomirenja. Zagreb, STEPress, 2002.

56 Papa Franjo, Fratelli tutti. Enciklika o bratstvu i socijalnom prijateljstvu. KS, Zagreb 2020., Dokumenti 187, br 1. Usp.: www.vatican.va/content/francesco/ en/encyclicals/documents/papa-francesco_20201003_enciclica-fratelli-tutti. html (27. 12. 2020.).

57 Usp. Angelus pape Franje na 26. 12. 2020. Vidi na: www.vaticannews.va/hr/ papa/news/2020-12/papa-franjo-angelus-sveti-stjepan-mucenici-geste-ljubavi. html (27. 12. 2020.). 
čimbenik za izgradnju kulture uvažavanja i socijalne kohezije. Ona je neizostavni dio suvremenoga vjeronaučnoga kurikula jer razvija senzibilitet $u$ pogledu ljudskih prava kao i tolerancije te međusobnog povjerenja među pojedincima i zajednicama.

Međureligijska kompetencija usvaja se ne samo konfesionalnom vjeronaučnom nastavom već i vrstom vjeronaučne nastave koja se naziva konfesionalno suradničko učenje iz razloga što ona još intenzivnije omogućuje usvajanje kompetencija suradnje, dijaloga i solidarnosti. Tako se međureligijska kompetencija potvrđuje kao korisno sredstvo za sprječavanje kulturnih, etničkih i religijskih sukoba, za uvažavanje različitosti i za stvaranje socijalne kohezije. Ona je sastavni dio tako potrebnog interkulturalnog obrazovanja ${ }^{58}$ koje promiče slobodu savjesti i mišljenja, uključuje slobodu pripadanja ili nepripadanja određenoj religiji, slobodu vjeroispovijesti, slobodu odricanja ili promjene vjerske opredijeljenosti, sukladno vlastitom nahođenju ${ }^{59}$.

Pretpostavljajući stavove uvažavanja, spremnosti na promjenu i uspostavljanje prijateljstava, međureligijska se kompetencija dokazuje kao neizostavna upravo u odgoju za suživot u pluralnom društvu. Stoga ona u religijskom obrazovanju ima ključnu ulogu u prihvaćanju stavova i vještina koji omogućuju razvoj tolerancije i poštovanja s obzirom na raznolikost kultura i religija. Susreti s drugim konfesijama, svjetonazorima i religijama odgajaju za toleranciju i pozitivno vrednovanje raznovrsnosti kultura i religija. Oni pridonose ekumenskom, međukulturnom i međureligijskom dijalogu te eksplicite promiču mir u svijetu.

\section{INTERRELIGIOUS COMPETENCE FROM THE PERSPECTIVE OF RELIGIOUS EDUCATION DIDACTICS}

\section{Summary}

The context of religious education in Europe is marked by cultural, religious and worldview pluralism. Therefore, the article, from a religious didactic perspective, deals with the criteria and elements that belong to interreligious competence in Catholic religion education.

58 Usp. Ružica Razum - Marija Jurišić (ur.), Interkulturalnost i religijsko obrazovanje u europskim dokumentima i kurikulumima / Interculturality and Religious Education in European Documents and Curricula, Zagreb, 2020., str. 5. 
The first chapter analyses the basic concepts related to the teaching of religion, with special emphasis on the distinction among the concepts of interreligious, multireligious, transreligious and transversal competence. The second chapter summarizes some religious didactic criteria, elements and principles of interreligious competence in confessional Catholic religion. The third chapter opens up new research perspectives within the field of comparative religious pedagogy. Assuming attitudes of respect, readiness for change and the establishment of friendships, interreligious competence proves to be indispensable precisely in the education for coexistence in a plural society. In religious education, it plays a key role in adopting attitudes and skills that enable the development of tolerance and respect considering the diversity of cultures and religions.

Key words: religious education didactics, interreligious and intercultural competence, freedom of worship, peace, solidarity, fraternity. 